\title{
Intellectual Capital Disclosure and Corporate Governance Structure: Evidence in Malaysia
}

\author{
Siti Mariana Taliyang (Corresponding author) \\ Department of Accounting, Faculty of Business Management and Accountancy \\ Universiti Sultan Zainal Abidin, Gong Badak Campus \\ Kuala Terengganu 21300, Terengganu, Malaysia \\ Tel: 60-96-653-750 E-mail: sitimariana@unisza.edu.my \\ Mariana Jusop \\ Department of Accounting, Faculty of Business Management and Accountancy \\ Universiti Sultan Zainal Abidin, Gong Badak Campus \\ Kuala Terengganu 21300, Terengganu, Malaysia \\ Tel: 60-96-653-750 E-mail: marianajusop@unisza.edu.my
}

Received: June 30, 2011

doi:10.5539/ijbm.v6n12p109
Accepted: July 25, $2011 \quad$ Published: December 1, 2011

URL: http://dx.doi.org/10.5539/ijbm.v6n12p109

\begin{abstract}
The objectives of this paper are to investigate the extent of the intellectual capital disclosure and the relationship between intellectual capital disclosure and corporate governance variables in Malaysian public listed companies. The independent variables tested in this study comprise various forms of corporate governance structure: (1) board composition, (2) role duality, (3) size of audit committee and (4) frequency of audit committee meetings. A sample of 150 companies listed in Bursa Malaysia was selected consisting of five industries which are Information Technology, Consumer Product, Industrial Product, Trading/Services and Finance. The descriptive statistics, content analysis and linear regression model were performed to analyze the data. Out of 4 variables tested, only the frequency of audit committee meeting has significant positive relationship in influencing the level of intellectual capital disclosure in Malaysia. The result also found 72.6 percent of the selected companies disclosed intellectual capital in their annual reports. However the extent of the intellectual capital disclosure among Malaysian companies is still relatively low about 3.45 percent. This result revealed that most of Malaysian companies are aware about the intellectual capital disclosure, however, they are not aware on how to measure, report and disclose this information in their annual report.
\end{abstract}

Keywords: Intellectual capital, Human capital, Relational capital, Structural capital, Corporate governance

\section{Introduction}

Intellectual capital (IC) disclosure has been receiving an increasing amount of attention among the companies around the world such as Australian companies, Italian companies and others. This is due to the new economy driven which is knowledge-based economy where value creation become one of the crucial issues in the world and tends to be based on intangible rather than tangible assets. In Malaysia, the development of human capital like empowerment of the human mentality and intellectual capacity of the nations is one of the targeted areas under the Ninth Malaysia Plan. To be competitive in the global market, a progressive developing Asian country like Malaysia has to effectively transfer from just being an input-driven to a knowledge-driven economy that focuses more on utilizing human knowledge and skills, rather than on productions of labor-intensive goods (Goh, 2005). Research by Tan (2000) found, only 0.2 percent of the total assets of the companies listed on the Bursa Malaysia (formerly known as Kuala Lumpur Stock Exchange) disclosed intangible assets other than goodwill. $\mathrm{He}$ also mentioned the number of companies reporting intangible assets was insignificant.

Since there is a global trend and demand for more useful and comprehensive non-financial information about the operating activities of firms (Anderson and Epstein, 1996), Malaysian companies should voluntarily disclosed intellectual capital in their annual reports. Thus, this study is conducted to investigate the extent of the 
intellectual capital disclosure and the relationship between intellectual capital disclosure and corporate governance variables among Malaysian listed companies especially after the revised Malaysian Code on Corporate Governance (MCCG), (revised, 2007). The key amendments to the Code emphasized on strengthening the board of directors' and audit committees' functions, eligibility criteria for appointment, the boards composition, the frequency of meetings and the need for continuous training. The Code requires public listed companies to report their compliance with the standards of corporate governance so that shareholders can assess the information. Therefore, it is expected that after the revision of MCCG, it might encourage the Malaysian firms to disclose more voluntary intellectual capital information in their annual reports.

The structure of the paper is organized as follows. Section 2 briefly discusses the relevant literature. The next section will succinctly discuss on data and methodology used in this study. Section 4 provides the empirical results and section 5 concludes the paper.

\section{Literature Review}

\subsection{Intellectual Capital Disclosure}

Intellectual capital is defined as intangible assets which include technology, customer information, brand name, reputation and corporate culture that are invaluable to a firm's competitive power (Low and Kalafut, 2002). Low and Kalafut conclude that intellectual capital consists of three components. The first component is tacit knowledge and innovativeness of the employees. The second component is infrastructure of human capital such as good working system, innovation and improvement processes of structural capital and the last components is external relationships of the firm such as customers' capital.

Nick Bontis, (Director, Institute of Intellectual Capital Research, Associate Editor, Journal of Intellectual Capital), states "Intellectual Capital is the currency of the new millennium. Managing it wisely is the key to business success in the knowledge era." There are many reasons for the companies to disclose intellectual capital information in their annual reports. They are (a) to help organizations formulate their strategies, (b) to assess strategy executions, (c) to assist in diversification and expansion decisions, (d) to use as basis for compensations and (e) to communicate measures to external stakeholders (Marr et al., 2003).

Currently, there are three approaches in measuring intellectual capital that have been suggested by Brennan (2001). The first approach is to employ existing value-based measures. It is suggested that the value of intellectual assets is the difference between the market value of the firm and its book value. A second approach is known as "Skandia Navigator" where this approach refers to the methods which identify and quantify the critical success factors in five dimensions of the company's business (Brennan, 2001). This model proposed by Edvinson and Malone (1997) express five dimensions; (1) financial; (2) client; (3) human; (4) processes; (5) renewal and development as an element of the intellectual capital system. The third approach refers to the Intellectual Capital Index. Through this approach, a key measures of success of an individual firm must be first identified and weighted (according to importance) to provide a single summary index. Some researchers argue a single aggregate measure is unhelpful (Booth, 1998).

To date, various studies has been done by many researchers to examine the determinants of intellectual capital disclosure around the world such as (Taliyang, 2011; Bruggen, 2009; White et al., 2007; Zaludin, 2007; Ousama Anam, 2007, Garcia-Meca et al., 2005) and many more. It can be concluded that a few variables such as company age, size, profitability and growth can be considered as control variables and significantly influence the level of intellectual capital disclosure for the companies.

\subsection{Corporate Governance and Disclosure Environment in Malaysia}

The Companies Act 1965 requires all public listed companies to prepare and submit their annual report to Companies Commission of Malaysia according to the reporting and disclosure standards prescribed by Malaysian Accounting Standard Board (MASB). Besides that, the government has also from time to time implemented a number of measures to enhance their standards of reporting and disclosure. The MCCG placed a significant milestone in corporate governance reform in Malaysia. It provided the guidelines of principles and best governance practices that emphasized on the importance of transparency, accountability, internal control, and board composition. Corporate governance served as mechanisms that assist firms to achieve their objectives while disclosure is an essential tool for reporting their corporate performance to investors. Keenan and Aggestam (2001), Li et al., (2008), Clemente and Labat (2009) and Akhtaruddin et al., (2009) argued that effective corporate governance mechanisms have impacts on efficient intellectual capital management, including the disclosure of information to stakeholders. The investors are to be informed about the core strengths of the company when it disclosed its intellectual capital owned (Kavida and Sivakoumar, 2008), thus, promoting the transparency. 


\subsection{Underlying Theory}

The underlying theory to be used in this study is agency theory. The theory provides the connection between voluntary disclosure behaviors to corporate governance where it was used as a control mechanism to reduce the agency problem arising from the separation between ownership and management (Welker, 1995). Additionally, high intellectual capital disclosure could provide more intensive monitoring package for a firm to reduce opportunistic behavior and information asymmetry ( $\mathrm{Li}$ et al., 2008). This is consistent with the study, by adopting corporate governance variables such as audit committee, independent board directors, separation of duty between roles of chairman and chief executive, may enhance the internal control in each of the companies and directly reduce the agency problems. As a consequence, it is expected that intellectual capital disclosure in annual reports could be improved.

\section{Data and Methodology}

\subsection{Hypotheses Development}

\subsubsection{Board composition}

The function of board of directors can be explained as an internal control mechanism in participating for decision making on behalf of the shareholders interest, also to ensure management decision is consistent with owner's interest. According to Haniffa and Cooke (2005), they suggest higher composition of non-executive directors on the board might influence the disclosure level as they can provide wider expertise, prestige and contacts for the company's benefits. However, Cotter and Silvester (2003) argue that independent non-executive directors are in a better position to monitor executive management. Extending this argument, we expect a company with more independent non-executive directors will disclose more information regarding the intellectual capital.

There are various studies which considered independent board composition as a possible determinant in influencing disclosure level: some studies found significant positive relationship between proportions of independent non-executive directors with voluntary disclosure (e.g. Li et al., 2008; Patelli and Prencipe, 2007). Hence the study argues that:

H1: There is positive relationship between independent board composition and intellectual capital disclosure

\subsubsection{Role duality}

Role duality is one of the criteria to examine the independence of board directors where leadership structure is hold by the same persons to undertake both the roles of chief executive and chairman in the organization. According to Forker (1992), a dominant personality in leading a firm may be detrimental to the interests of shareholders, and this phenomenon has been found to be associated with poor disclosure. Extending to this argument for role duality as for independent non-executives, we hypothesize that:

\section{H2: There is negative relationship between role duality and intellectual capital disclosure}

\subsubsection{Audit committee size}

The appointment of audit committee from the non-executive directors who are financially literate is made with the objective to ensure that the interests of shareholders are properly protected. This is because the role of audit committee is to review the preparation of company's financial statements as well as the disclosure of value-relevant information such as intellectual capital. According to Ho and Wong (2001), the presence of effective audit committee serves as the best mechanism to increase intellectual capital disclosure, improve internal control, and enhance quality of information. This is contrary to the findings from the study made by Mangena and Pike (2005) and Akhtarudin et al. (2009) that indicated the size of the audit committee does not impact the extent of the disclosure in annual reports. However, recent studies related to this issue made by Li et al. (2008) and Ruth L. Hidalgo et al. (2011) found that companies with the larger audit committees usually disclose greater intellectual capital in their annual reports. We address the competing views by testing the following hypothesis:

\section{H3: There is positive relationship between audit committee size and intellectual capital disclosure}

\subsubsection{Frequency of audit meeting}

The revised MCCG require audit committee to hold not less than four (4) meetings a year. The audit committee and the external auditor should meet regularly, without the executive board members present, to encourage a greater exchange of free and honest views and opinions between both parties. Olson (1999) noted that inactive audit committees are unlikely to monitor management effectively and adequate meeting time should be devoted to the consideration of major issues. This is supported by Li et al. (2008) that the level of intellectual capital disclosure and frequency of audit committee meetings are positively related to each other. Both studies 
suggested that audit committee activity is an important factor in monitoring management behavior, specifically to reduce information asymmetry through intellectual capital disclosure.Based on the increasing importance of this matter, we expect the audit committees to have more meetings to influence the disclosure of intellectual capital in the company. Therefore, we hypothesize that:

\section{H4: There is positive relationship between frequency of audit committee meetings and intellectual capital disclosure}

\subsection{Variables Measurement}

\subsubsection{Measurement for intellectual capital disclosure (dependent variable)}

In order to measure intellectual capital disclosure, the study used intellectual capital disclosure index by replicating a modified methodology by Bontis (2003) and Vergauwen and Van Alem (2005), that is, the 36intellectual capital related terms collected by researchers in the World Congress on Intellectual Capital. The congress categorized the 36 terms into three categories; (a) human capital; (b) structural capital and (c) relational capital. Because of the presence of some general terms related to the field of intellectual capital, Bruggen (2009) in his study modified the model by placing additional terms into the fourth category called "General Terms". None of relational capital terms appear in the sample firm's annual report. Hence, this study uses three additional terms to be tested. The additional terms are (1) investor relation; (2) customer relation; (3) supplier relation. It is expected that, these three terms will give significant result in this study since some of the samples are operating in Financial and Information Technology sectors. It is assumed that, these companies are highly involved in the relation with customers, suppliers and investors. Hence, these three items in relational capital should be added to this measurement.

\subsubsection{Measurement for independent variables}

The factors which were being studied in examining the relationship to intellectual capital disclosure are:

(i) Composition of board independence (BCOMP) - proportion of independence director over total board of directors.

(ii) Role duality (RDUAL) - give 1 if the roles of chairman and CEO are held by same person; 0 if otherwise.

(iii) Audit committee size (SAC) - total number of directors on the audit committee.

(iv) Meeting of audit committee (MAC) - frequency of audit committee meeting held within the financial year.

\subsection{Data Collection and Analysis}

A sample of 150 companies listed in Bursa Malaysia was randomly selected consisting of five industries which are Information Technology, Consumer Product, Industrial Product, Trading/Services and Finance. The study used a secondary data gathered from sources of annual reports of the companies. Annual reports of 2009 were used to extract the relevant information. The 2009 annual reports were chosen as they had incorporated several changes as stipulated in the revised Malaysian Code of Corporate Governance (MCCG). It is expected after the revision of MCCG (2007); Malaysian companies are more interested to disclose voluntary information in their annual reports.

The first part of the analysis is describing the demographic and financial characteristics of the sample firms. Descriptive analysis is carried out using Statistical Package for the Social Science (SPSS). Next, the content analysis was performed. This method allows the content of the annual reports of the relevant companies to be investigated with regard to the use of certain words in the annual reports. In carrying this analysis, firstly, computer scanning system has been used in scanning the annual reports of the companies and detecting the related IC terms which appear in the annual reports. In enhancing the reliability of the data gathered, the terms which appear in the annual reports have been cross- checked through manually reading the related pages which consist of the appeared terms.

Lastly, the terms that have been detected, would be counted for the number of it appeared in the annual report for the year. In counting the number of terms appeared in the annual reports, the study ignored the terms that appear in the director's profile, the name of the seminar or activities, and the repetitions of an award's name. This is because the terms that appeared in the sections mentioned above did not make sense in measuring the total of the intellectual capital disclosure among Malaysian companies. For example, the directors of the companies hold a degree in Information System. The term of information system in this sentence do not symbolize as a structural capital. Hence, it is practical to disregard this term in calculating the frequencies of IC disclosure among Malaysian companies. The result of the analysis on the content of annual reports is shown in Table 3 and Table 4 . Additionally, the Ordinary Least Square (OLS) regression was performed for testing the hypothesis using SPSS version 14. The following regression equation was estimated to identify the relationship between corporate governance variables and IC disclosure. The results of OLS regression equation were presented in Table 5. 


$$
\text { IC Disclosure }=\beta_{0}=\beta_{1}(B C O M P)-\beta_{2}(R D U A L)+\beta_{3}(S A C)+\beta_{4}(M A C)+\varepsilon_{i}
$$

Where;

$\begin{array}{ll}\operatorname{IC~Disclosure}_{i} & =\text { Intellectual capital disclosure of company } i \\ \mathrm{BCOMP}_{i} & =\text { composition of independence directors in company } i \\ \operatorname{RDUAL}_{i} & =\text { implementation of role duality in company } i \\ \mathrm{SAC}_{i} & =\text { size of audit committee in company } i \\ \mathrm{MAC}_{i} & =\text { frequency of audit committee meetings in company } i \\ \beta_{0} & =\text { Constant } \\ \beta_{1}-\beta_{4} & =\text { Coefficient of the explanatory variables } \\ \varepsilon_{\mathrm{i}} & =\text { Error or disturbance terms of company } i\end{array}$

\section{Empirical Results}

\subsection{Descriptive Results}

Reported result in Table 1 includes the mean, standard deviation, minimum and maximum value for each of the variables involve in this study except for role duality. The mean for intellectual capital disclosure was shown at 3.45 percent as indicated in Table 1. Besides that, the mean for role duality was tested using independent sample test and the result shown in Table 2. The result in Table 2 shows there is a bit difference for the mean for role duality as it indicates 2.4 percent if the roles of chairman and CEO are held by same person and 3.6 percent if otherwise.

\subsection{Content Analysis Results}

Table 3 shows that structural capital is the most frequently disclosed category followed by the relational capital. In contrast, the result found by Bruggen (2009) stated that it was very hard to find relational capital items disclosed in the annual reports of Australian firms. The differences above is consistent with the expectation that by adding some extra terms under relational capital would give significant influence to this study compared to the study done by Bruggen (2009). It clearly shows that Malaysian firms absolutely engaged in investor, customer and supplier relation. Besides that, by scrutinizing all industries selected, the results found, companies in finance and information technology disclosed more intellectual capital items than the other industries. The study supports the result found by Bruggen (2009), where Australian firms involves in High-tech industries and Information System were among the industries that commonly report on intellectual capital information.

Of the 39-IC related terms, only 15 terms appeared in the annual reports of Malaysian listed companies as shown in Table 4. Of those terms, "human capital" was frequently disclosed with a score at 138 times followed by investor relation at 111 and information system at 97 . Additionally, out of 150 samples, the result also found that 72.67 percent of the companies disclosed IC in their annual reports. Only 27.33 percent of the companies are not disclosing IC. This percentage reflects a very high disclosure of IC in Malaysia.

Besides that, in terms of disclosure location, IC information is reported in several sections in the annual reports. This information is commonly appeared in the financial statements and notes to financial statements, followed by director's report, statement of corporate governance and other operational report. Intellectual capital work is mostly managed by senior management Bontis (2001), so the location of IC disclosure demonstrates company's concerns in reporting intellectual capital.

\subsection{Regression Result}

Table 5 shows the regression result if the estimated equation was run simultaneously between all independent variables and dependent variable. Using two-tailed test, the only statistically significant coefficient is frequency of audit meetings since significance level is 0 , means $\mathrm{p}<0.01$. It shows, when a company held recurrently audit meetings, it encourage directors for disclosing voluntary information in their annual report. Thus, the result supports the hypothesis. However, the R-squared show 0.169 which means $16.9 \%$ of the corporate governance variables used in this study determined the level of intellectual capital disclosure among Malaysian companies.

\section{Concluding Comments}

The objectives of this paper are to investigate the extent of the intellectual capital disclosure and the relationship between intellectual capital disclosure and corporate governance variables in Malaysia. The independent variables tested in this study comprise various forms of corporate governance structure: (1) board composition, (2) role duality, (3) size of audit committee and (4) frequency meeting of audit committee. A sample of 150 companies listed in Bursa Malaysia was selected consisting of five industries which are Information Technology, Consumer Product, Industrial Product, Trading/Services and Finance. 
It can be concluded that, even though the result showed the high percentage of about 72.6 percent of the companies selected disclosed intellectual capital in their annual reports, but the extent of the intellectual capital disclosure among those companies is still relatively low. It is indicated by the average intellectual capital disclosure of 3.45 percent. The low level of the extension of IC disclosure is due to the measurement used in this study where, the extent of IC disclosure is measured by dividing the number of items disclosed by the companies with the total items used in this study for each category of IC. In calculating the number of items disclosed, the repetition of the same items in the annual report is disregard in this study.

The result also revealed that most of Malaysian companies are aware about the intellectual capital disclosure, however, they are not aware on how to measure, report and disclose this information in their annual report. This is consistent with the conclusion made by Gutherie and Petty (2000). They conclude that the Australian companies report less on IC disclosure in their annual reports due to the poor understanding, inadequately identified, inefficiently managed and reported IC in a consistent framework.

Besides that, out of four corporate governance variables tested, only frequency of the audit meeting can be concluded as factor which positively influencing the level of intellectual capital disclosure among Malaysian listed companies. This is supported by Li et al. (2008) that the level of intellectual capital disclosure and frequency of audit committee meetings are positively related to each other. However, the result did not support the other three hypotheses since the study found that there is no significant relationship between board composition, role duality and audit committee size with intellectual capital disclosure. The same result also found by previous studies as Ho and Wong (2001); Brammer and Pavelin (2006) found no relationship between board composition and intellectual capital disclosure while Li et.al (2008) conclude role duality was not found to influence intellectual capital disclosure. Akhtaruddin et.al (2009) found the audit committee size on the board is not related to voluntary disclosures.

Adoption of internal control devices, such as audit committees and non-executive directors, and separation of the roles of chairman and chief executive, may enhance monitoring quality in critical decisions about intellectual capital investment and performance (Keenan and Aggestam, 2001). However, our study found that no significant relationship between such internal control devices with the voluntary intellectual capital disclosure. One of the possible reasons might be non-executive directors not necessarily independent. As defined by Cotter and Silvester (2003), independent non-executive directors are typically individuals with relevant expertise and professional reputations to defend, with no management role or links with the company.

It must be noted that this study has limitations. Firstly, the study was done in a limited time and had to be completed within a period of three months. Therefore, a sample size is limited to 150 companies and of one- year data only. Thus small sample might not comprehensively or accurately illustrate the real situation occur in Malaysia. Additionally, the study focused on Malaysia, thus the result cannot be generalized to other countries. The second limitation is related to content analysis. Analyzing the annual reports based on the specified list of intellectual capital (IC) means it may not provide the whole picture of IC disclosure practices in Malaysia. According to Striukova et al. (2008), there are various types of corporate reports used by companies to communicate their intellectual capital information, thus annual reports alone are not good proxies for measuring extent of IC disclosure. As this study used a modified methodology by Bontis (2003) and Vergauwen and Van Alem (2005), a major limitation of using this methodology is that 39 items used. Finally, the last limitation in this study is that an annual report is analyzed using computer scanning in deriving the number of items that that appear in the annual report. Hence, the computer could skip a similar item with different wordings. The study could be improved in the future in several ways. As this study has been conducted using a small sample and one year data because of the time limitation, to make the conclusion more reliable, a bigger sample size could be undertaken in future. To further improve the research, the sample could be widened and focus on all companies listed in Main Market. The number of years could also be increased to five years in order to see the pattern or trend of the intellectual capital disclosure among Malaysian companies. If all the above suggestions above are taken into consideration, perhaps more conclusive result could be obtained in the future.

\section{References}

Akhtaruddin, M., Hossain, M. A., Hossain, M., and Yao, L. (2009). Corporate Governance and Voluntary Disclosure in Corporate Annual Reports of Malaysian Listed Firms. Journal of Applied Management Accounting Research, (Winter):1-20.

Anderson, R.H., and Epstein, M.J. (1996). The Usefulness of Corporate Annual Reports to Shareholders in Australia, New Zealand, and the United States: An International Comparison. Studies in Managerial and Financial Accounting, Vol. 4, Elsevier Science, Amsterdam.

Bontis, N. (2001). Assessing Knowledge Assets: A Review of the Models Used to Measure Intellectual Capital. International Journal of Management Reviews, 3(1), pp 41-60. http://dx.doi.org/10.1111/1468-2370.00053 
Bontis, N. (2003). Intellectual Capital Disclosure in Canadian Corporations. Journal of Human Resource Costing \& Accounting, 7(1), pp 9-20. http://dx.doi.org/10.1108/eb029076

Booth, R. (1998). The Measurement of Intellectual Capital. Management Accounting (UK), 76 (10), pp 26-28.

Brammer, S., and Pavelin, S. (2006). Voluntary Environmental Disclosures by Large UK Companies, Journal of Business Finance and Accounting, 33(7/8), pp.1168-1188. http://dx.doi.org/10.1111/j.1468-5957.2006.00598.x

Brennan, N. (2001). Reporting Intellectual Capital in Annual Reports: Evidence from Ireland. Accounting, Auditing \& Accountability Journal, 14(4), pp. 423-436. http://dx.doi.org/10.1108/09513570110403443

Bruggen A. (2009). Intellectual Capital Disclosure: Evidence from Australia. Management Decision Journal, 47(2), pp. 233-245. http://dx.doi.org/10.1108/00251740910938894

Clemente, A. G., and Labat, B. N. (2009). Corporate Governance Mechanisms and Voluntary Disclosure. The Role of Independent Directors in the Boards of Listed Spanish Firms. Research Projects of Madrid Autonomous University.

Cotter, J., and Silverster, M. (2003). Board and Monitoring Committee Independence. Abacus, 39(2), pp. 211-232. http://dx.doi.org/10.1111/1467-6281.00127

Edvinson, L., and Malone, M. (1997). Intellectual Capital: The Proven Way to Establish Your Company's Real Value by Measuring Its Hidden Brain Power, Piatkus, London.

Forker, J. J. (1992). Corporate Governance and Disclosure Quality. Accounting and Business Research, 22(86), pp. 111-124.

Garcia-Meca, E., and Martinez, I. (2005). Assessing the Quality of Disclosure on Intangibles in the Spanish Capital Market. European Business Review, 17(4), pp. 305-313. http://dx.doi.org/10.1108/09555340510607352

Goh, P.C. (2005). Intellectual Capital Performance of Commercial Banks in Malaysia. Journal of Intellectual Capital, 6(3), 385-396. http://dx.doi.org/10.1108/14691930510611120

Guthrie, J., and Petty, R. (2000). Intellectual Capital: Australian Annual Reporting Practices. Journal of Intellectual Capital, 1(2/3), pp. 241-51. http://dx.doi.org/10.1108/14691930010350800

Haniffa, M. R., and Cooke T. E. (2005). The Impact of Culture and Governance on Corporate Social Reporting, Journal of Accounting and Public Policy, 24 pp. 391-430. http://dx.doi.org/10.1016/j.jaccpubpol.2005.06.001

Ho, S. S. M., and Wong, K. S. (2001). A Study of the Relationship between Corporate Governance Structures and the Extent of Voluntary Disclosure. Journal of International Accounting, Auditing \& Taxation, 10(2), pp. 139-156. http://dx.doi.org/10.1016/S1061-9518(01)00041-6

Kavida, V., and Sivakoumar. N. (2008). Corporate Governance in Knowledge Economy. The Relevance of Intellectual Capital. Research Project, Pondicherry, India.

Keenan, J., and Aggestam, M. (2001). Corporate Governance and Intellectual Capital: Some Conceptualisations. Corporate Governance, 9(4), pp.259-275. http://dx.doi.org/10.1111/1467-8683.00254

Li, J., Pike, R., and Haniffa, R. (2008). Intellectual Capital Disclosure and Corporate Governance Structure in UK Firms. Accounting and Business Research, 38(2), pp.137-159. http://dx.doi.org/10.1080/00014788.2008.9663326

Low, J., and Kalafut. (2002). Invisible Advantage - How Intangibles are Driving Business Performance. Perseus Publishing, Cambridge.

Mangena, M., and Pike, R. (2005). The Effect of Audit Committee Shareholding, Financial Expertise and Size on Interim Financial Disclosures. Accounting and Business Research, 35 (4), pp. 327-349.

Marr, B., Mouritsen, J., and Bukh, P.N. (2003). Perceived Wisdom. Financial Management, July/August, p. 32.

Olson, J. (1999). How to Make Audit Committees More Effective. Business Lawyer, 54, pp. 1097-1113.

Ousama A. (2007). The Trends and Determinants of Intellectual Capital Disclosure by Malaysian Listed Companies. Unpublished master's thesis, IIUM, Malaysia.

Patelli, L., and Prencipe, A. (2007). The Relationship between Voluntary Disclosure and Independent Directors in the Presence of A Dominant Shareholder. European Accounting Review, 16(1), pp.5-33. http://dx.doi.org/10.1080/09638180701265820

Ruth L. Hidalgo, Garcia-Meca, E., and Martinez, I. (2011). Corporate Governance and Intellectual Capital Disclosure, Journal of Business Ethics, 100, pp. 483-495. http://dx.doi.org/10.1007/s10551-010-0692-x

Striukova, L., Unerman, J., and Guthrie, J. (2008). Corporate Reporting of Intellectual Capital: Evidence from 
UK Companies. The British Accounting Review, 40(4), pp.297-313. http://dx.doi.org/10.1016/j.bar.2008.06.001

Taliyang, S.M. (2011). Determinants of Intellectual Capital Disclosure among Malaysian Listed Companies. Unpublished master's thesis, UUM, Malaysia.

Tan, L.T. (2000). Financial Accounting Reporting in Malaysia. Professional Advancement Achievement Centre, Kuala Lumpur.

Vergauwen, P.G.M.C., and Van Alem, F.J.C. (2005). Annual Report: IC Disclosure in the Netherlands, France and Germany. Journal of Intellectual Capital, 6(1), pp. 89-104. http://dx.doi.org/10.1108/14691930510574681

Welker, M. (1995). Disclosure Policy, Information Assymmetry and Liquidity in Equity Markets. Contemporary Accounting Research, 11 pp. 801-828. http://dx.doi.org/10.1111/j.1911-3846.1995.tb00467.x

White G. (2007). Drivers of Voluntary Intellectual Capital Disclosure in Listed Biotechnology Companies. Journal of intellectual capital, 8(3), pp 517-537. http://dx.doi.org/10.1108/14691930710774894

Zaludin, Z. (2007). Factors Influencing Intellectual Capital Disclosure: Malaysian Evidence. Unpublished master's thesis, IIUM, Malaysia.

Table 1. Descriptive Result

\begin{tabular}{|l|c|c|c|c|}
\hline & Mean & Std.Deviation & Min & Max \\
\hline Board composition & 0.4638 & 0.1317 & 0.2500 & 0.8600 \\
\hline Audit committee size & 3.3400 & 0.7310 & 2.0000 & 7.0000 \\
\hline Frequency audit meetings & 5.0900 & 1.5410 & 2.0000 & 16.000 \\
\hline Total IC disclosure & 0.0345 & 0.0301 & 0.0000 & 0.1282 \\
\hline
\end{tabular}

Table 2. Independent T-Test

\begin{tabular}{|c|c|c|c|}
\hline & RDUAL & $\mathrm{N}$ & Mean \\
\hline TOTAL_IC & 1 & 20 & .024359 \\
\hline & 0 & 130 & .036095 \\
\hline
\end{tabular}

Table 3. Intellectual Capital Disclosure - by Industry

\begin{tabular}{|l|c|c|c|c|c|}
\hline \multicolumn{1}{|c|}{ Industry / Items } & $\begin{array}{c}\text { Human } \\
\text { Capital }\end{array}$ & $\begin{array}{c}\text { Structural } \\
\text { Capital }\end{array}$ & $\begin{array}{c}\text { Relational } \\
\text { Capital }\end{array}$ & $\begin{array}{c}\text { General } \\
\text { Terms }\end{array}$ & Total \\
\hline Information Technology & 19 & 51 & 12 & 1 & 83 \\
\hline Consumer Product & 17 & 17 & 12 & 1 & 47 \\
\hline Industrial Product & 6 & 16 & 14 & 0 & 36 \\
\hline Trading / Services & 26 & 23 & 20 & 0 & 69 \\
\hline Finance & 75 & 52 & 93 & 1 & 221 \\
\hline Total & $\mathbf{1 4 3}$ & $\mathbf{1 5 9}$ & $\mathbf{1 5 1}$ & $\mathbf{3}$ & $\mathbf{4 5 6}$ \\
\hline
\end{tabular}


Table 4. Intellectual Capital Disclosure - by Terms

\begin{tabular}{|c|c|c|c|c|c|c|c|}
\hline $\begin{array}{l}\text { Human } \\
\text { Capital }\end{array}$ & Times & $\begin{array}{c}\text { Structural } \\
\text { Capital }\end{array}$ & Times & $\begin{array}{c}\text { Relational } \\
\text { Capital }\end{array}$ & Times & $\begin{array}{c}\text { General } \\
\text { Items }\end{array}$ & Times \\
\hline $\begin{array}{l}\text { Employee } \\
\text { expertise }\end{array}$ & 0 & $\begin{array}{l}\text { Structural } \\
\text { capital }\end{array}$ & 0 & $\begin{array}{l}\text { Relational } \\
\text { capital }\end{array}$ & 0 & $\begin{array}{l}\text { Economic } \\
\text { value added }\end{array}$ & 0 \\
\hline $\begin{array}{l}\text { Employee } \\
\text { know-how }\end{array}$ & 0 & $\begin{array}{l}\text { Intellectual } \\
\text { property }\end{array}$ & 54 & $\begin{array}{l}\text { Supplier } \\
\text { knowledge }\end{array}$ & 0 & $\begin{array}{l}\text { Intellectual } \\
\text { capital }\end{array}$ & 2 \\
\hline $\begin{array}{l}\text { Employee } \\
\text { knowledge }\end{array}$ & 0 & $\begin{array}{l}\text { Cultural } \\
\text { diversity }\end{array}$ & 0 & $\begin{array}{l}\text { Customer } \\
\text { knowledge }\end{array}$ & 0 & $\begin{array}{l}\text { Intellectual } \\
\text { resources }\end{array}$ & 0 \\
\hline $\begin{array}{l}\text { Employee } \\
\text { productivity }\end{array}$ & 0 & $\begin{array}{l}\text { Organizational } \\
\text { structure }\end{array}$ & 0 & $\begin{array}{l}\text { Customer } \\
\text { capital }\end{array}$ & 0 & $\begin{array}{l}\text { Intellectual } \\
\text { asset }\end{array}$ & 0 \\
\hline $\begin{array}{l}\text { Employee } \\
\text { skill }\end{array}$ & 1 & $\begin{array}{l}\text { Corporate } \\
\text { learning }\end{array}$ & 1 & $\begin{array}{l}\text { Company } \\
\text { reputation }\end{array}$ & 0 & $\begin{array}{l}\text { Knowledge } \\
\text { asset }\end{array}$ & 0 \\
\hline $\begin{array}{l}\text { Employee } \\
\text { value }\end{array}$ & 1 & $\begin{array}{l}\text { Organizational } \\
\text { learning }\end{array}$ & 0 & $\begin{array}{l}\text { Investor } \\
\text { relation }\end{array}$ & 111 & $\begin{array}{l}\text { Knowledge } \\
\text { stock }\end{array}$ & 0 \\
\hline Human capital & 138 & $\begin{array}{l}\text { Corporate } \\
\text { university }\end{array}$ & 0 & $\begin{array}{l}\text { Customer } \\
\text { relation }\end{array}$ & 40 & $\begin{array}{l}\text { Intellectual } \\
\text { material }\end{array}$ & 0 \\
\hline Human asset & 1 & $\begin{array}{l}\text { Knowledge } \\
\text { sharing }\end{array}$ & 2 & $\begin{array}{l}\text { Supplier } \\
\text { relation }\end{array}$ & 0 & $\begin{array}{l}\text { Business } \\
\text { knowledge }\end{array}$ & 1 \\
\hline Human value & 2 & $\begin{array}{l}\text { Management } \\
\text { quality }\end{array}$ & 2 & & & $\begin{array}{l}\text { Competitive } \\
\text { intelligence }\end{array}$ & 0 \\
\hline \multirow[t]{3}{*}{ Expert team } & 0 & $\begin{array}{l}\text { Knowledge } \\
\text { management }\end{array}$ & 3 & & & & \\
\hline & & $\begin{array}{l}\text { Information } \\
\text { system }\end{array}$ & 97 & & & & \\
\hline & & $\begin{array}{l}\text { Expert } \\
\text { network }\end{array}$ & 0 & & & & \\
\hline Total & 143 & & 159 & & 151 & & 3 \\
\hline
\end{tabular}

Table 5. Regression result

\begin{tabular}{|l|c|c|c|c|c|}
\hline & \multicolumn{2}{|c|}{$\begin{array}{c}\text { Unstandardized } \\
\text { Coefficients }\end{array}$} & $\begin{array}{c}\text { Standardized } \\
\text { Coefficients }\end{array}$ & $\mathrm{t}$ & Sig. \\
\hline & $\mathrm{B}$ & Std. Error & Beta & & \\
\hline BCOMP & .009 & .018 & .041 & .516 & .607 \\
\hline RDUAL & -.010 & .007 & -.115 & -1.501 & .136 \\
\hline SAC & .000 & .003 & .004 & .045 & .965 \\
\hline MAC & .007 & .002 & .381 & 4.795 & $.000^{* * *}$ \\
\hline $\mathrm{R}^{2}$ & \multicolumn{5}{|l}{0.169} \\
\hline
\end{tabular}

Note: $* * *$ significant at 1 percent; $* *$ significant at 5 percent; $*$ significant at 10 percent. 